\title{
Recent In Situ/Operando Spectroscopy Studies of Heterogeneous Catalysis with Reducible Metal Oxides as Supports
}

\author{
Fei Wang ${ }^{1}$, Jianzhun Jiang ${ }^{2, *}$ and Bin Wang ${ }^{2, *}$ \\ 1 State Key Laboratory of Coal Conversion, Institute of Coal Chemistry, Chinese Academy of Sciences, \\ Taiyuan 030001, China; wangfei908@sxicc.ac.cn \\ 2 Beijing Research Institute of Chemical Industry, Sinopec Group, Beijing 100013, China \\ * Correspondence: jiangjz.bjhy@sinopec.com (J.J.); wangbin.bjhy@sinopec.com (B.W.)
}

Received: 28 April 2019; Accepted: 21 May 2019; Published: 23 May 2019

\begin{abstract}
For heterogeneous catalysis, the metal catalysts supported on reducible metal oxides, especially $\mathrm{CeO}_{2}$ and $\mathrm{TiO}_{2}$, have long been a research focus because of their excellent catalytic performance in a variety of catalytic reactions. Detailed understanding of the promotion effect of reducible metal oxides on catalytic reactions is beneficial to the rational design of new catalysts. The important catalytic roles of reducible metal oxides are attributed to their intimate interactions with the supported metals (e.g., strong metal-support interaction, electronic metal-support interaction) and unique support structures (e.g., oxygen vacancy, reversible valence change, surface hydroxyl). However, the structures of the catalysts and reaction mechanisms are strongly affected by environmental conditions. For this reason, in situ/operando spectroscopy studies under working conditions are necessary to obtain accurate information about the structure-activity relationship. In this review, the recent applications of the in situ/operando spectroscopy methodology on metal catalysts with reducible metal oxides as supports are summarized.
\end{abstract}

Keywords: metal catalysts; reducible metal oxides; in situ/operando spectroscopy methodology

\section{Introduction}

The development of spectral characterization techniques has had a significant impact on catalysis science in revealing the structure-activity relationship [1,2]. By virtue of spectroscopy methodology (e.g., XRD, XAFS, IR, Raman, XPS), the geometrical and electronic structures of the catalytic active site and reaction intermediates can be well characterized. However, they are strongly affected by environmental conditions (atmosphere, temperature, pressure, etc.) [3]. Based on the characterization results in ex situ conditions, an incorrect structure-activity relationship will probably be obtained. It is therefore important to accurately simulate the realistic operation conditions by applying appropriate in situ cells in spectroscopy studies. With the development of in situ/operando spectroscopy methodology, it provides an effective way to identify the intrinsic active sites and corresponding reaction intermediates in real catalytic reactions $[4,5]$.

Reducible oxides (e.g., $\mathrm{TiO}_{2}, \mathrm{CeO}_{2}$ ) supported metal catalysts have attracted extensive attention, due to their excellent catalytic performance in many important reactions (e.g., CO oxidation [6-9], water-gas shift reaction [10-13], $\mathrm{CO}_{2}$ hydrogenation reactions [14-18]). The reducible oxides are supposed to play roles via several routes, including intimate metal-support interactions (e.g., oxides encapsulation of metal nanoparticles [19], electronic interactions [20], metal nanoparticle stabilization [21]) and high-performance metal-support interfacial active sites (e.g., support participation in catalysis [22]). In order to distinguish which of them is the most important, great efforts have been devoted to obtaining 
structural information of active sites and reaction mechanisms by applying situ/operando spectroscopy methodology under practical conditions.

In the present work, apart from addressing the key scientific problems encountered by heterogeneous catalysis with reducible oxides as supports, the emphasis is on recent contributions of in situ/operando spectroscopy studies that try to address these problems. We propose current challenges and future strategies for further development of in situ/operando spectroscopy studies in this area.

\section{Intimate Metal-Support Interaction}

\subsection{Strong Metal-Support Interaction}

The strong metal-support interaction (SMSI) was reported to suppress the capacity of group 8 noble metals to adsorb hydrogen and carbon monoxide by Tauster [23]. Great efforts have been made to understand the SMSI between metals and reducible supports $[24,25]$. The microscopic techniques play a key role in revealing the structural basis of SMSI, which was found to be the formation of an overlayer of the reducible oxide material across the metal surface [26-29]. In addition, the combination of both in situ spectroscopic and microscopic techniques (e.g., near-ambient pressure scanning tunneling microscopy) is an effective strategy to study the structure-activity relationship at a molecular level [30,31].

The detailed adsorption and activation properties of the metal catalysts fully covered by oxide overlayer are rarely reported. It is commonly thought that the oxide overlayer is apt to cover all the metal site, which renders catalysts inactive. Chen et al. constructed two kinds of $\mathrm{TiO}_{\mathrm{x}} / \mathrm{Pt}(111)$ surfaces to simulate the SMSI state [32]. The evaluation results in CO oxidation showed that the fully covered oxide layer on Pt can increase its catalytic activity, with much lower apparent activation energy compared with that of $\mathrm{Pt}(111)$ surface. In situ wide spectral range, infrared reflection adsorption spectroscopy (IRAS), was used in this work to monitor the surface reaction and $\mathrm{TiO}_{\mathrm{x}}$ model surfaces under reaction condition. A weak characteristic peak attributed to $\mathrm{CO}\left(2092 \mathrm{~cm}^{-1}\right)$ was detected both in the reaction gas and pure $\mathrm{CO}$ atmosphere (Figure 1A). Combined with inactivity of titanium oxide itself for $\mathrm{CO}$ oxidation, the active site was deduced to be exposed Pt atoms, which is located at the boundary of the domains of $\mathrm{TiO}_{x}$ layer. Figure 1B showed that the characteristic peaks of Ti-O vibrational modes $\left(1000-500 \mathrm{~cm}^{-1}\right)$ are stable in the reaction, proving the stability of the SMSI state in this work. The above work provided an ideal encapsulation model with thin oxide overlayer on metal to study the structure-activity relationship in the fully covered SMSI state. The in situ IR showed its advantage in detecting the exposed metal atom with $\mathrm{CO}$ as the probe molecule.
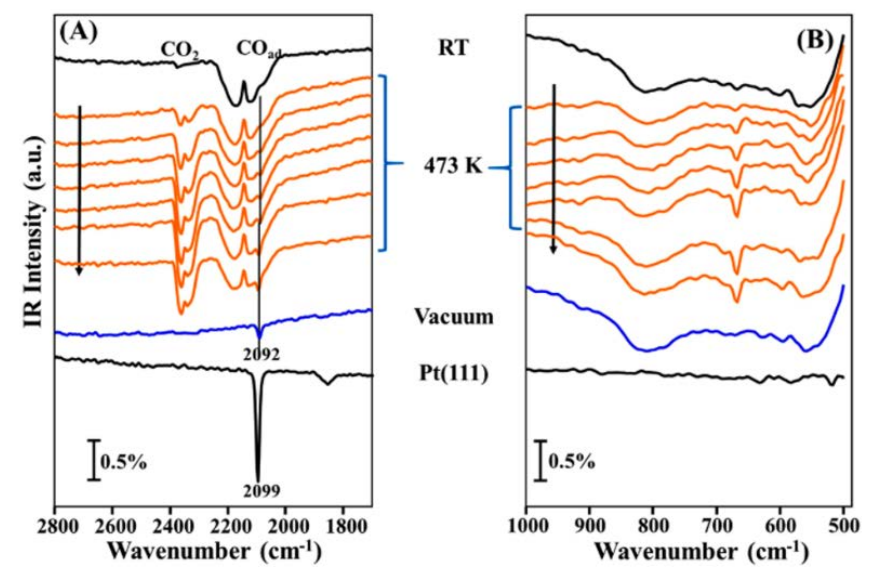

Figure 1. (A and B) In situ IRAS spectra for CO oxidation on the $1 \mathrm{ML}\left(\mathrm{TiO}_{\mathrm{x}}-\mathrm{Re}\right.$ ) film at $473 \mathrm{~K}$. Reprinted with permission from Reference [32]. Copyright 2018, American Chemical Society.

\subsection{Adsorbate-Mediated SMSI}

The above work realized the enhancement of the catalytic activity of Pt catalysts by precious control of the thickness of the oxide overlayer. However, this preparation method is a high cost for the real 
catalysts. Christopher et al. found an adsorbate-mediated SMSI (A-SMSI) effect, which can construct a permeable oxide overlayer for real catalysts [33]. For the Ru nanoparticles supported on $\mathrm{TiO}_{2}$ and $\mathrm{Nb}_{2} \mathrm{O}_{5}$, the A-SMSI encapsulation state was constructed by the treatment in $\mathrm{CO}_{2}-\mathrm{H}_{2}$ atmosphere at 150-300 ${ }^{\circ} \mathrm{C}$. In situ IR spectroscopy (Figure 2) showed that the treatment in $20 \mathrm{CO}_{2}: 2 \mathrm{H}_{2}$ atmosphere leads to the formation of formate $\left(\mathrm{HCO}_{2}, 1531\right.$ and $\left.1351 \mathrm{~cm}^{-1}\right)$ and a bicarbonate-like species on the $\mathrm{TiO}_{2}$ surface $\left(\mathrm{HCO}_{3}, 1444 \mathrm{~cm}^{-1}\right)$. At the same time, the redshift and decreased intensity of the $\mathrm{CO}$ characteristic peak was due to charge transfer from $\mathrm{TiO}_{\mathrm{x}}$ to $\mathrm{Rh}$ and the partial physical blocking of metal sites. Combined with the previous reports of $\mathrm{HCO}_{\mathrm{x}}$-induced $\mathrm{TiO}_{2}$ reduction [34-36], the A-SMSI effect was proven. Although the A-SMSI state covered the Ru nanoparticles, the oxide overlayer was permeable for reactants which provided a possible method to modulate the catalytic selectivity with acceptable activity. In this work, the in situ IR shows its advantage in detecting the adsorbed species.

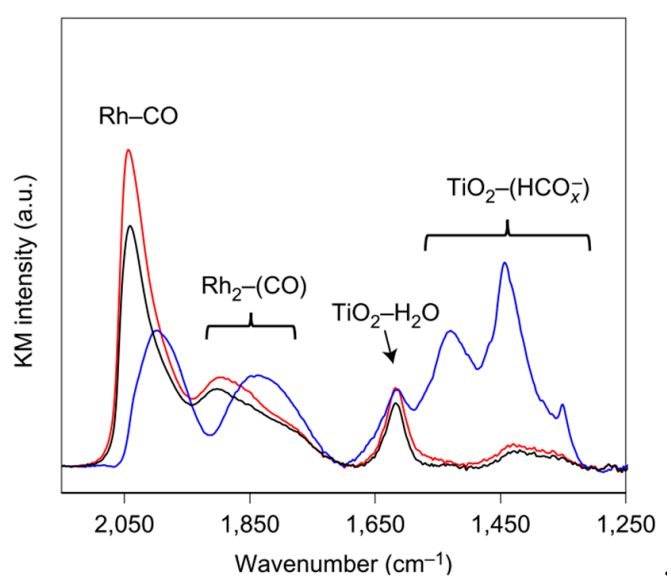

Figure 2. In situ DRIFT spectra collected from $2 \% \mathrm{Rh} / \mathrm{TiO}_{2}$ at the reaction conditions $\left(180{ }^{\circ} \mathrm{C}, 1 \%\right.$ $\mathrm{CO}_{2}, 1 \% \mathrm{H}_{2}, 98 \% \mathrm{He}$ ) for reduced (red), $20 \mathrm{CO}_{2}: 2 \mathrm{H}_{2}$ treated (blue), re-reduce (black) catalysts. On $20 \mathrm{CO}_{2}: 2 \mathrm{H}_{2}$ treatment, the $\mathrm{CO}$ stretching frequency of linear and bridge Rh-carbonyl groups decreased by $50 \mathrm{~cm}^{-1}$, their intensity dropped twofold and $\mathrm{TiO}_{2}$-bound $\mathrm{HCO}_{\mathrm{x}}$ species appeared. Re-reduction reversed all the effects of the $20 \mathrm{CO}_{2}: 2 \mathrm{H}_{2}$ treatment. Reprinted with permission from Reference [33]. Copyright 2016, Springer Nature.

\subsection{Wet-Chemistry SMSI Effect}

The constructions of classical SMSI often rely on the redox treatments at high temperature, which probably result in sintering of the supported metal and loss of the surface area. Recently, Xiao et al. proposed the wet-chemistry SMSI (wcSMSI) effect for $\mathrm{Au} / \mathrm{TiO}_{2}$ catalysts [37]. By a redox interaction between $\mathrm{Au}^{\delta+}$ and $\mathrm{Ti}^{3+}$, the $\mathrm{Au}$ nanoparticles can be covered by $\mathrm{TiO}_{\mathrm{x}}$ overlayer. In situ UV-vis spectroscopy and XPS were used to study the redox interaction in this process. For the $\mathrm{TiCl}_{3}$ solution, there was a sole peak attributed to $\mathrm{Ti}^{3+}$ (Figure 3A-a, 205 230 nm). When the acidity was decreased by adding a slight amount of $\mathrm{NaHCO}_{3}$, the bands of $\mathrm{TiO}_{2}$ showed redshift $(210-260 \mathrm{~nm})$. This is due to the hydrolysis of $\mathrm{TiCl}_{3}$. When the Au nanoparticles were introduced into the solution, the peak intensity of $\mathrm{Ti}^{3+}$ increased greatly, confirming the fast formation of abundant $\mathrm{TiO}_{x}$ species (Figure $3 \mathrm{~A}-\mathrm{f}$ ). When $\mathrm{TiCl}_{3}$ was introduced into the Au colloid, the drastically increased band of $\mathrm{Ti}^{3+}$ also showed up. These results confirmed the strong redox interaction in the preparation process.

The XPS spectra (Figure 4) showed that the chemical state of Au colloids is primarily metallic $\mathrm{Au}(87.5$ and $83.8 \mathrm{eV})$ and $\mathrm{Au}^{+}$species $(88.4$ and $84.7 \mathrm{eV})$. After the adding of $\mathrm{Ti}^{3+}$ solution, the $\mathrm{Au}$ species converted to negatively charge $\mathrm{Au}^{\delta-}(87.1$ and $83.4 \mathrm{eV})$. At the same time, the signals of $\mathrm{Ti}^{3+}$ diminished, indicating the transformation of $\mathrm{Ti}^{3+}$ to $\mathrm{Ti}^{4+}$ in this process. In addition, for the metal catalysts on the inert support, the methodology can also be used to tune their catalytic performance via $\mathrm{TiO}_{\mathrm{x}}$ overlayer capsulation. In this work, the in situ spectroscopy methodology showed its wide suitability to various conditions, including the liquid environment. 

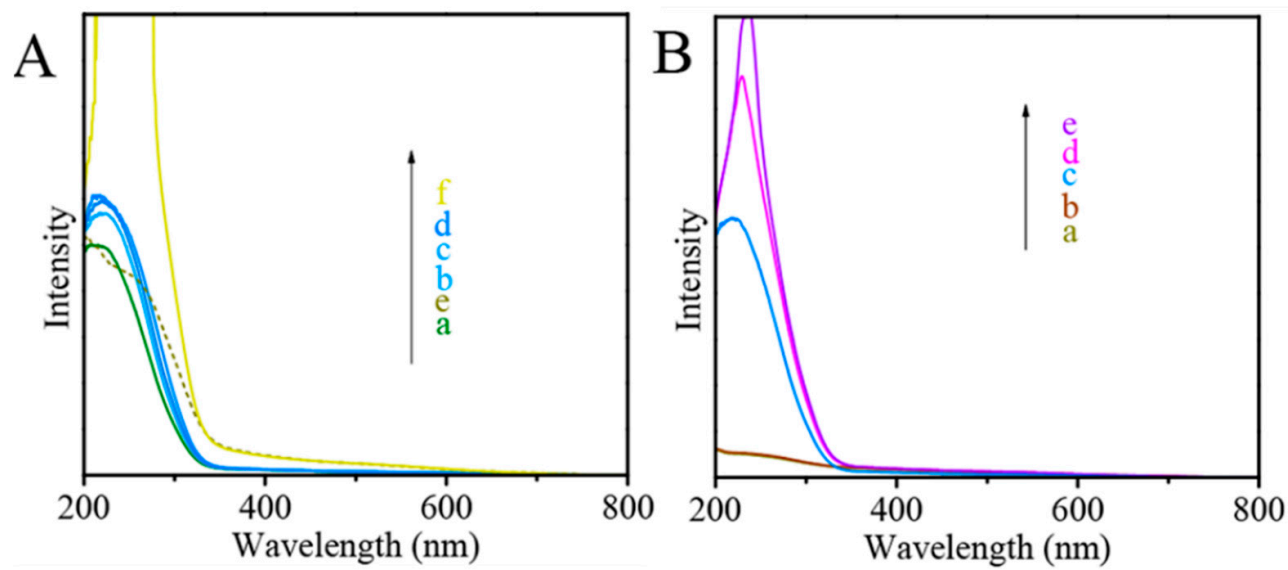

Figure 3. (A) UV-vis spectra of $\mathrm{TiCl}_{3}$ aqueous solution $(10 \mathrm{mg} / \mathrm{mL})$ under different treatments: (a) Fresh, (b) 40 , (c) 80 , and (d) $200 \mu \mathrm{L}$ of $\mathrm{NaHCO}_{3}$ aqueous solution $(4 \mathrm{mg} / \mathrm{mL})$ was added, and (e) $750 \mu \mathrm{L}$ of $\mathrm{NaHCO}_{3}$ aqueous solution and $0.2 \mathrm{~mL}$ of Au nanoparticle colloid were added into (a), (f) $0.2 \mathrm{~mL}$ of Au nanoparticle colloid was added into (d); (B) UV-visible spectra of various liquors (a and $\mathbf{b}) \mathrm{Au}$ nanoparticle colloid with Au concentration at (a) 0.68 and (b) $6.8 \mathrm{mg} / \mathrm{L}$, (c-e) $40 \mu \mathrm{L}$ of $\mathrm{TiCl}_{3}$ aqueous solution $(0.37 \mathrm{mg} / \mathrm{mL})$ was added into $(\mathbf{c}) \mathrm{H}_{2} \mathrm{O}$, (d) colloid a and (e) colloid b. Reprinted with permission from Reference [37]. Copyright 2019, American Chemical Society.
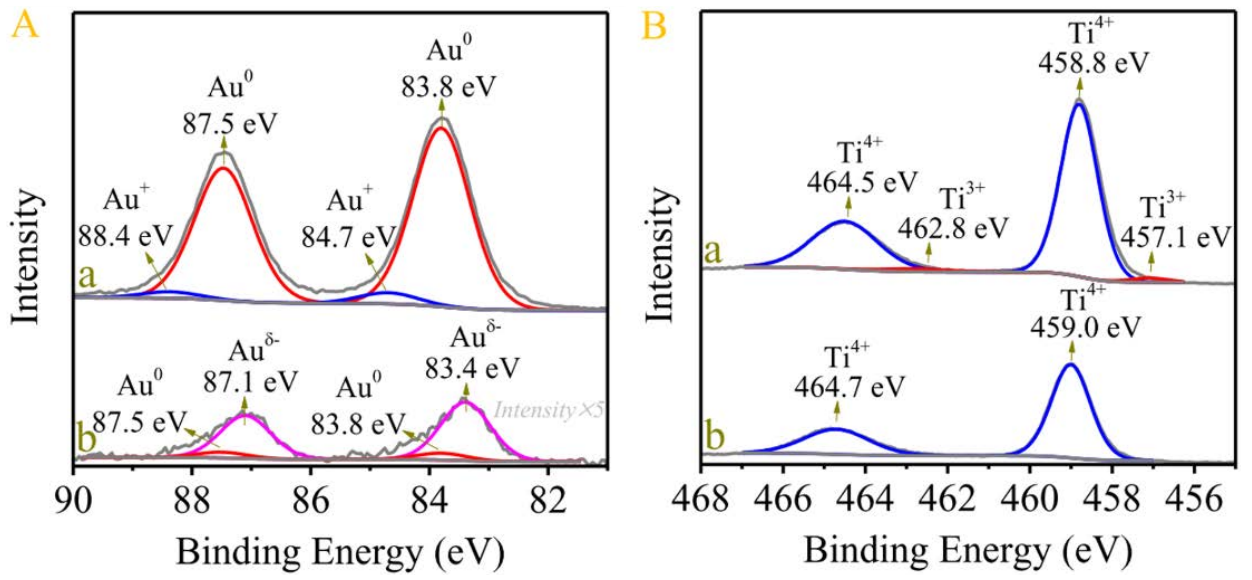

Figure 4. (A) Au4f XPS spectra of Au nanoparticles (a) pretreated with $\mathrm{O}_{2}$ and (b) interacted with $\mathrm{Ti}^{3+}$; (B) Ti2p XPS spectra of the (a) as-synthesized $\mathrm{TiO}_{\mathbf{x}}$ colloid and (b) interacting with Au nanoparticle colloid. Reprinted with permission from Reference [37]. Copyright 2019, American.

\subsection{Electronic Metal-Support Interactions}

In 2012, Rodriguez found a new type of strong metal-support interaction in $\mathrm{Pt} / \mathrm{CeO}_{2}$ catalyst, which produces large electronic perturbations for small $\mathrm{Pt}$ particles in contact with ceria [38]. This interaction substantially enhanced the catalytic activity of the catalyst in the dissociation of the $\mathrm{O}-\mathrm{H}$ bonds in water. This type of metal-support interaction was coined as electronic metal-support interactions (EMSI) by Campbell [39]. The EMSI often leads to a special structure-activity relationship at the metal-support interfacial site, which will be discussed in the following section.

\section{The Active Site at the Metal-Support Interface}

In addition to the full encapsulation of metal nanoparticles with the oxide overlayer, the partially covered state results in abundant metal-support interfacial sites. At the metal-support interface, the charge transfer and support participation can greatly modulate the structures of the active sites which is significantly different from that on the metal surface. The structure-activity relationship at the 
metal-support interfacial sites in catalytic reactions is summarized here, including $\mathrm{CO}$ oxidation, water-gas shift reaction, $\mathrm{CO}_{2}$ hydrogenation, etc.

\subsection{CO Oxidation}

The best catalysts for low-temperature $\mathrm{CO}$ oxidation are metal catalysts supported on or promoted by reducible metal oxides, such as $\mathrm{CeO}_{2}$ and $\mathrm{TiO}_{2}[22,40,41]$. There are still many open questions about this catalytic reaction system, especially the key factor in determining the reaction rate.

\subsubsection{The Adsorption of $\mathrm{CO}$ on $\mathrm{Au}$ and $\mathrm{TiO}_{2}$ at the Metal-Support Interface}

The separate bulk $\mathrm{Au}$ and $\mathrm{TiO}_{2}$ are inactive in $\mathrm{CO}$ oxidation. Compared with them, the $\mathrm{Au} / \mathrm{TiO}{ }_{2}$ catalysts showed high catalytic activity in $\mathrm{CO}$ oxidation at low temperature. For the traditional view, the $\mathrm{Au}$ atoms at the metal-support interface are thought to be the active site. However, the support sites are only thought to be involved in stabilizing $\mathrm{O}_{2}$. Yates Jr. et al. observed dual catalytic sites at the metal-support interface on $\mathrm{Au} / \mathrm{TiO}_{2}$ catalyst in $\mathrm{CO}$ oxidation [42]. The kinetic change of adsorbed $\mathrm{CO}$ on both $\mathrm{Au}$ and $\mathrm{TiO}_{2}$ sites at the metal-support interface was monitored with in situ infrared spectroscopy (Figure 5). The CO-FTIR spectra showed the characteristic peaks of $\mathrm{CO}$ adsorbed on $\mathrm{TiO}_{2}$ $\left(2179 \mathrm{~cm}^{-1}\right)$ and $\mathrm{Au}\left(2102 \mathrm{~cm}^{-1}\right)$, respectively (Figure 5A). When the $\mathrm{Au} / \mathrm{TiO}_{2}$ catalyst with saturated $\mathrm{CO}$ was exposed to $\mathrm{O}_{2}$ at $120 \mathrm{~K}$, the $\mathrm{CO}$ adsorbed on $\mathrm{TiO}_{2}$ disappeared gradually while $\mathrm{CO}$ adsorbed on $\mathrm{Au}$ remain almost stable (Figure $5 \mathrm{~B}$ ). In addition, almost no $\mathrm{CO}$ oxidation was found on pure $\mathrm{TiO}_{2}$, indicating the key role of the metal-support interface. In response to a higher temperature, the $\mathrm{CO}$ adsorbed on the Au sites begin to participate in the catalytic reaction. In this work, the in situ IR showed its advantage in clearly discriminating the $\mathrm{CO}$ adsorbed on different sites at the metal-support interface $\left(\mathrm{Au}\right.$ and $\left.\mathrm{TiO}_{2}\right)$.
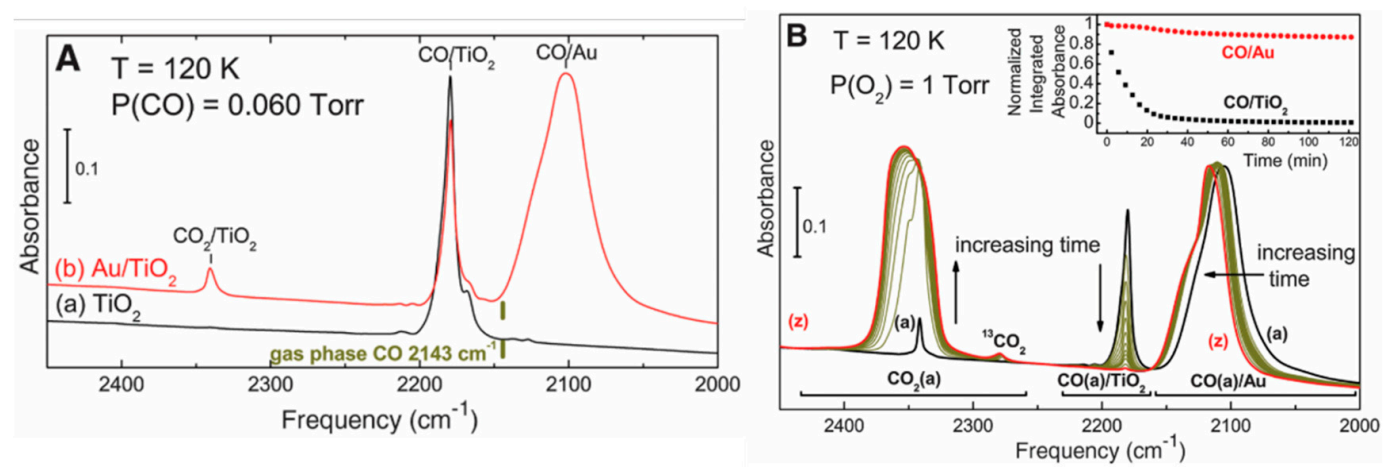

Figure 5. (A) IR spectra of saturated $\mathrm{CO}$ layer: Spectrum $\mathrm{a}, \mathrm{TiO}_{2} ; \mathrm{b}, \mathrm{Au} / \mathrm{TiO}_{2}$ under 0.060 torr of $\mathrm{CO}$ pressure at $120 \mathrm{~K}$. (B) IR spectral development during the $\mathrm{CO}$ oxidation reaction on $\mathrm{Au} / \mathrm{TiO} \mathrm{O}_{2}$ under 1 torr of $\mathrm{O}_{2}$ pressure at $120 \mathrm{~K}$ : a, before $\mathrm{O}_{2}$ introduction; $\mathrm{z}$, after $120 \mathrm{~min}$ of reaction. The $\mathrm{CO} / \mathrm{TiO}_{2}$ oxidation was found to continue when the $\mathrm{CO}$ coverage was replenished from spectrum $\mathrm{z}$, indicating that the $\mathrm{CO}_{2}$ (a) accumulation did not block the active sites. (Inset) The plot of normalized integrated absorbance of $\mathrm{CO} / \mathrm{Au}$ (red) and $\mathrm{CO} / \mathrm{TiO}_{2}$ (black) against time during the experiment. Reprinted with permission from Reference [42]. Copyright 2011, The American Association for the Advancement of Science.

\subsubsection{The Adsorption of $\mathrm{CO}$ on $\mathrm{Au}$ Nanoparticle with Bulk Reduced $\mathrm{TiO}_{2}$ Support}

Behm et al. investigated the EMSI on bulk reduced $\mathrm{Au} / \mathrm{TiO}_{2}$ catalysts with in situ IR spectroscopy measurements [43]. As key evidence to prove how the EMSI affects the catalytic performance of the bulk reduced $\mathrm{Au} / \mathrm{TiO}_{2}$ catalyst, the in situ IR spectroscopy measurements revealed significant differences between the $\mathrm{CO}$ adsorption properties of metal nanoparticles supported on bulk-reduced (CO-pretreated at $\left.400{ }^{\circ} \mathrm{C}, \mathrm{CO} 400\right)$ and defect-poor $\left(\mathrm{O}_{2}\right.$-pretreated at $\left.400{ }^{\circ} \mathrm{C}, \mathrm{O} 400\right) \mathrm{Au} / \mathrm{TiO}_{2}$ catalysts (Figure 6). For the CO400 catalyst exposed to the reaction gas mixture, the strong peak at $2119 \mathrm{~cm}^{-1}$ 
is assigned to $\mathrm{CO}_{\mathrm{ad}}$ on $\mathrm{Au}$ nanoparticles (Figure $6 \mathrm{~A}$ ). The intensity of this peak is stable for over 1000 min (Figure 6B). For the $\mathrm{O} 400$ catalyst, however, the peak of $\mathrm{CO}_{\mathrm{ad}}$ on Au nanoparticles shows a red shift to $2116 \mathrm{~cm}^{-1}$ which proves that the Au nanoparticles are negatively charged. At the same time, this peak is very weak at the beginning of the reaction, showing the lower coverages of $\mathrm{CO}_{\mathrm{ad}}$. This peak gradually increases with time, together with a blue shift (from 2116 to $2119 \mathrm{~cm}^{-1}$ ). These in situ spectroscopy studies clearly show that the EMSI on bulk-reduced $\mathrm{Au} / \mathrm{TiO}_{2}$ catalysts has a strong modification to the $\mathrm{CO}$ adsorption strength on the Au nanoparticles and likely results in lower activity in the $\mathrm{CO}$ oxidation reaction. In their following work, at $-20{ }^{\circ} \mathrm{C}$, the in situ IR further reveals that EMSI leads to a different reaction mechanism compared with the Au-assisted Mars-van Krevelen mechanism in this work [44].
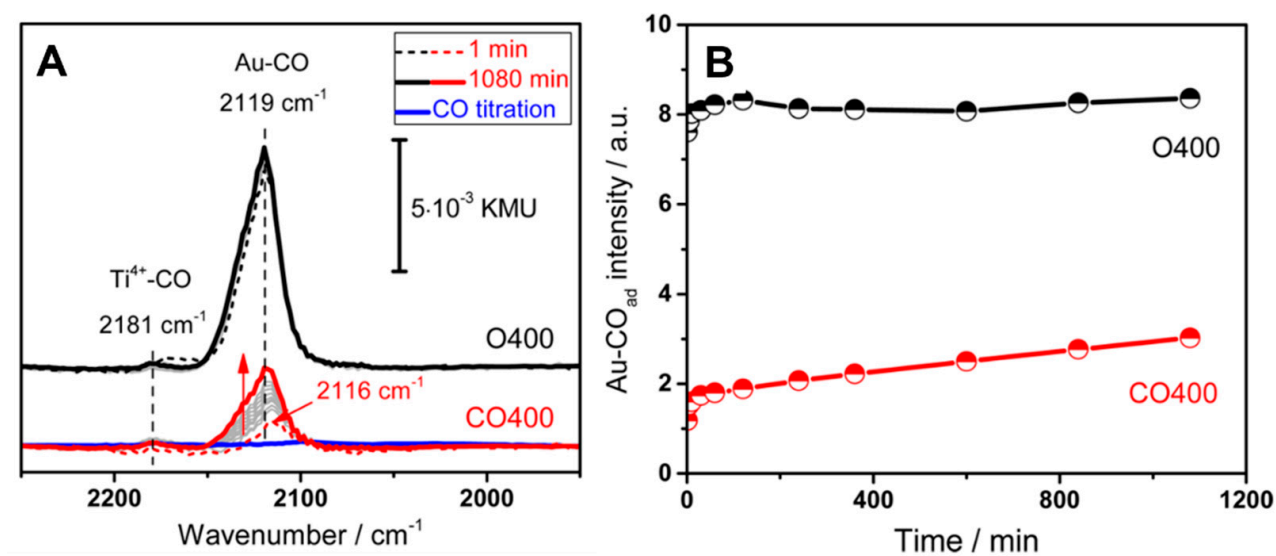

Figure 6. (A) Sequence of in situ DRIFT spectra recorded during CO oxidation $\left(1 \% \mathrm{CO}, 1 \% \mathrm{O}_{2}\right.$, balance $\mathrm{N}_{2}$ ) on $\mathrm{Au} / \mathrm{TiO}_{2}$ at $80{ }^{\circ} \mathrm{C}$ directly after in situ pre-treatment at $400{ }^{\circ} \mathrm{C}$ in oxidative $\left(\mathrm{O} 400: 10 \% \mathrm{O}_{2} / \mathrm{N}_{2}\right)$ or reductive (CO400: $10 \% \mathrm{CO} / \mathrm{N}_{2}$ ) atmosphere. For comparison, we also show a spectrum recorded during CO adsorption ( $1 \% \mathrm{CO}$, balance $\mathrm{N}_{2}, 10 \mathrm{~min}$ ) on a CO400 catalyst. For all spectra, the gas phase $\mathrm{CO}$ signal is already subtracted. (B) Temporal evolution of the $\mathrm{CO}_{\mathrm{ad}}$ band intensity during these measurements. Reprinted with permission from Reference [43]. Copyright 2017, American Chemical Society.

\subsubsection{The Participation of $\mathrm{Ce}^{3+}$ Species in the Reaction at the $\mathrm{Pt} / \mathrm{CeO}_{2}$ Interface}

For $\mathrm{CO}$ oxidation catalyzed by $\mathrm{CeO}_{2}$-based metal catalysts ( $\mathrm{Pt}, \mathrm{Pd}$, and $\mathrm{Ni}$ ), kinetic studies proved that the reaction rate of $\mathrm{CO}$ oxidation depends on the length of the metal-support interface, rather than the nature of the metal [38]. However, the active sites and the rate-determining steps are still unclear at the molecular level. Safonova et al. applied time-resolved resonant X-ray emission spectroscopy (RXES) to quantitatively monitor the kinetics of formation and consumption of $\mathrm{Ce}^{3+}$ species of $\mathrm{Pt} / \mathrm{CeO}_{2}$ catalyst in the working conditions [45]. Figure 7 (B-E) shows the $\mathrm{Ce}^{3+}$ concentration measured by RXES in the atmosphere from mixed reaction gas to $\mathrm{CO}$ at different reaction temperatures. The initial rate of $\mathrm{Ce}^{3+}$ oxidation is very fast, which indicates the high activity of $\mathrm{Ce}^{3+}$. In addition, the $\mathrm{Ce}^{3+}$ does not completely disappear, proving the presence of $\mathrm{Ce}^{3+}$ spectator species uninvolved in the reaction. When the oxygen supply is switched off at $60 \mathrm{~s}$, the concentration of $\mathrm{Ce}^{3+}$ increases immediately, proving the participation of oxygen from the support in the catalytic process. In this work, the relationship between the concentration of $\mathrm{Ce}^{3+}$ and the switched gas atmosphere clearly proved the high activity of partial $\mathrm{Ce}^{3+}$ in the reaction. 


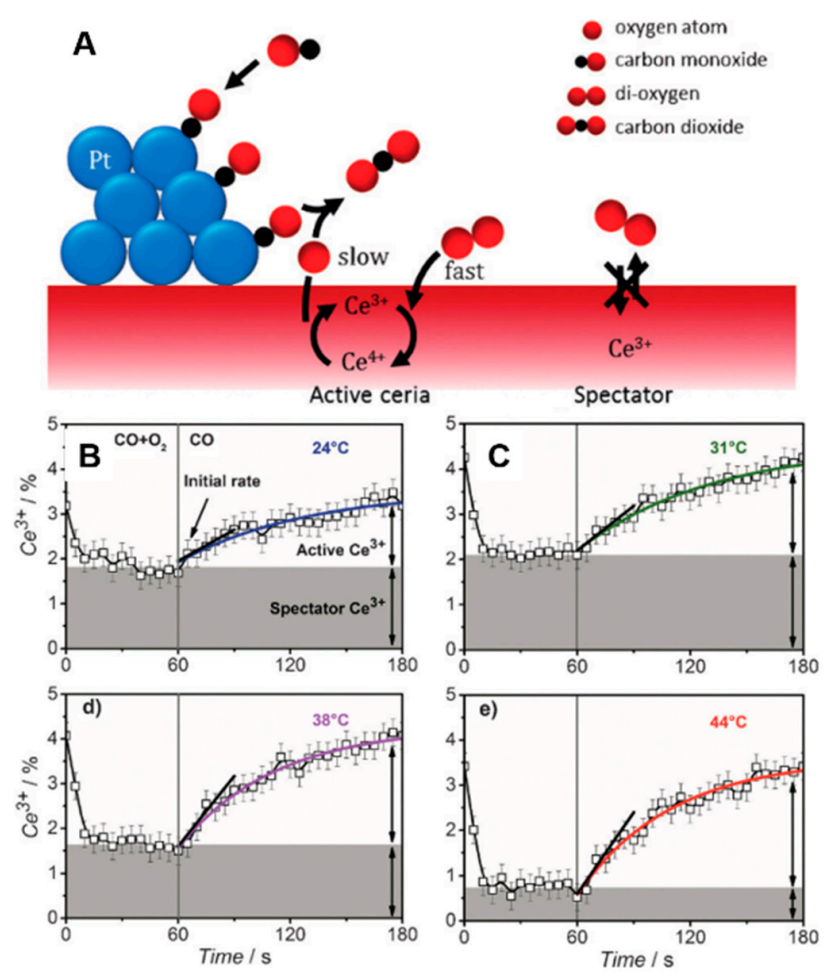

Figure 7. (A) Representation of oxygen uptake and release by ceria during the CO oxidation cycle on a $\mathrm{Pt} / \mathrm{CeO}_{2}$ catalyst. In the slow part of the cycle, an oxygen atom from ceria at the $\mathrm{Pt}-\mathrm{CeO}_{2}$ interface reacts with $\mathrm{CO}$ adsorbed on platinum to afford $\mathrm{CO}_{2}$, an oxygen vacancy, and two $\mathrm{Ce}^{3+}$ species. The fast part of the cycle involves $\mathrm{CO}$ readsorption on platinum and oxygen activation on ceria resulting in healing of the oxygen vacancy and oxidation of active $\mathrm{Ce}^{3+}$ species. $\mathrm{Ce}^{3+}$ spectator species do not participate in CO oxidation. (B-E) Transient $\mathrm{Ce}^{3+}$ concentrations in the $\mathrm{Pt} / \mathrm{CeO}_{2}$ catalyst measured with $\mathrm{RXES}$ during cycling between $1 \% \mathrm{CO}+4 \% \mathrm{O}_{2}(0-60 \mathrm{~s})$ and $1 \% \mathrm{CO}(60-180 \mathrm{~s})$ gas mixtures at $24,31,38$, and $44{ }^{\circ} \mathrm{C}$. The increase in $\mathrm{Ce}^{3+}$ concentration in $1 \% \mathrm{CO}$ was fitted by an exponent function and the initial rate at the moment of switching ( $60 \mathrm{~s}$ ) was determined (indicated as the slope). The concentrations of active and spectator $\mathrm{Ce}^{3+}$ species are indicated by arrows. Reprinted with permission from Reference [45]. Copyright 2015, John Wiley and Sons.

3.1.4. The Adsorbate-Driven Metal-Metal Oxide Interface Formation on the Surface of Bimetal Catalysts

In addition to the prepared metal-reducible metal oxide catalysts, Park et al. found that the interfacial Metal-Metal oxide nanostructures (Pt-NiO) are formed under a reaction condition (CO oxidation reaction) in bimetal $\left(\mathrm{Pt}_{3} \mathrm{Ni}(111)\right)$ alloy surface, which are highly active in the $\mathrm{CO}$ oxidation reaction [46]. A similar interfacial nanostructure $(\mathrm{Pt} / \mathrm{CoO})$ was also found on $\mathrm{PtCo}$ bimetallic nanoparticles during $\mathrm{H}_{2}$ oxidation reaction [47]. The combined in situ microscopic and spectroscopic techniques in these works helped to prove the formation of interfacial Metal-Metal oxide nanostructure.

\subsection{Methane Oxidation}

The reducible oxide supports play an important role in both total methane oxidation (TMO) and catalytic partial oxidation of methane (CPOM). Osman et al. found that $\mathrm{TiO}_{2}$ support improves oxygen transport to Pd while the acidic support (H-ZSM-5) activates the methane and modifies the electrophilicity of $\mathrm{Pd}$ in the TMO reaction, resulting in the high activity at very low temperature $\left(200{ }^{\circ} \mathrm{C}\right)$ [48]. For the CPOM catalyzed by Ni/CeO $2-\mathrm{ZrO}_{2} / \mathrm{ZSM}-5$, the interfacial area between $\mathrm{Ni}$ and reducible metal oxides are highly active and stable. The reducible metal oxides can improve the redox cycle of Ni and supply oxygen to remove the deposited carbon [49]. The in situ/operando spectroscopic technique is relatively rarely used in this research field. In 2014, Fouladvand et al. employed the transient in situ infrared spectroscopy method to study the reaction intermediates in methane oxidation 
over supported Pt catalysts [50]. The platinum-ceria interface is thought to be the additional active site resulting in the generally higher catalytic activity. In 2018, a combination of STEM-EDX and XPS analyses showed that the most active catalyst structure for combustion catalyst is dominated by alumina, with Ti found around the edges. The bimetallic Pd-Pt metals are similar to each other, dispersed across the support structure with a fairly random distribution. Thus, this work gives more information on the catalytic structure of a combustion catalyst [51].

\subsection{Water-Gas Shift Reaction (WGSR)}

The WGSR is an important reaction used for hydrogen production and removing CO in feed streams of fuel cells. The supports significantly affect the catalytic performance in this reaction. Osman et al. found that using acidic supports led to different interaction and synergetic effect between the two most active phases of $\mathrm{Pt}$ metal and $\mathrm{Mo}_{2} \mathrm{C}$, thus the acidity played a crucial role herein [52]. Metal nanoparticles supported on reducible metal oxides show great catalytic performance in this field. Both experimental and computational studies proved that the synergistic effect of metals and oxygen vacancies in the supports can promote the reactivity of the catalysts $[13,53]$.

\subsubsection{The EMSI at $\mathrm{Ni}^{\delta-}-\mathrm{O}_{\mathrm{v}}-\mathrm{Ti}^{3+}$ Interfacial Site}

We have reported a $\mathrm{TiO}_{2-x}$-modified $\mathrm{Ni}$ nanocatalyst $\left(\mathrm{Ni} @ \mathrm{TiO}_{2-\mathrm{x}}\right)$ with tunable EMSI for WGS reaction [54]. In situ EXAFS verified that the increased electron density of $\mathrm{Ni}\left(\mathrm{Ni}^{\mathrm{\delta}-}\right)$ results from the gradually increased reduction temperature (Figure 8). The adsorption edges of the normalized $\mathrm{Ni}$ K-edge XANES spectra display a gradual shift toward low photon energy with the increasing reduction temperature compared with the $\mathrm{Ni}$ foil, indicating the enhanced EMSI (Figure 8A). In the same process, the metallic $\mathrm{Ni}-\mathrm{Ni}$ distance decreased gradually with a peak shift in Figure 8B. In addition, Figure 3C,D show that the A2 prepeaks (at $\sim 4970.5 \mathrm{eV}$ ) increase and shift to lower energy, proving the existence of five-coordinated Ti atoms. The above results proved the presence of EMSI and the resulting $\mathrm{Ni}^{\delta-}-\mathrm{O}_{\mathrm{v}}-\mathrm{Ti}^{3+}$ interfacial site.

(A)

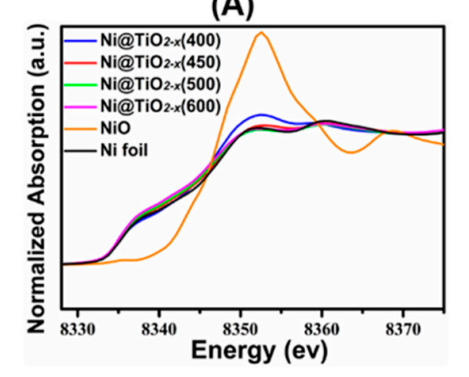

(B)

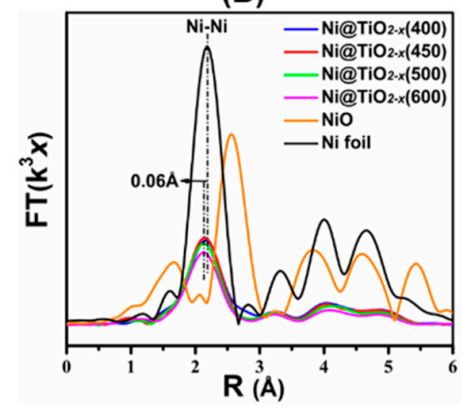

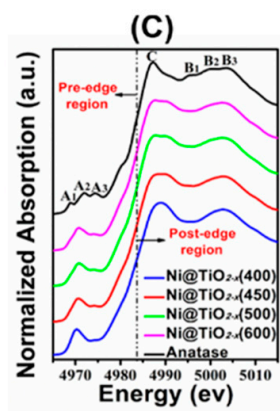

(D)

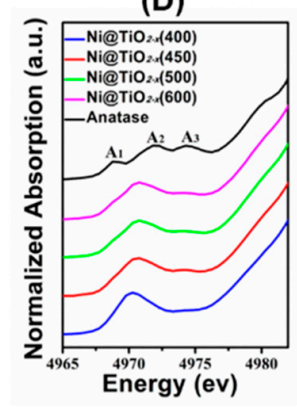

Figure 8. (A) Normalized XANES spectra at Ni K-edge for $\mathrm{Ni}_{\mathrm{TiO}} \mathrm{Ti}_{2-\mathrm{x}}(400), \mathrm{Ni} @ \mathrm{TiO}_{2-\mathrm{x}}(450)$, $\mathrm{Ni} @ \mathrm{TiO}_{2-x}(500)$, and $\mathrm{Ni} @ \mathrm{TiO}_{2-x}(600)$, respectively. (B) Fourier-transform EXAFS spectra at $\mathrm{Ni}$ K-edge for $\mathrm{NiO}$ reference, $\mathrm{Ni} @ \mathrm{TiO}_{2-x}(400), \mathrm{Ni}_{\mathrm{TiO}} \mathrm{Tix}_{2}(450), \mathrm{Ni}_{\mathrm{TiO}} \mathrm{Tix}_{2}(500), \mathrm{Ni}_{\mathrm{TiO}} \mathrm{Tix}_{2}(600)$, and $\mathrm{Ni}$ foil, respectively. (C) Normalized XANES spectra at Ti K-edge for $\mathrm{Ni}_{\mathrm{TiO}} \mathrm{Tix}_{2-\mathrm{C}}(400), \mathrm{Ni}_{\mathrm{TiO}} \mathrm{Tix}_{2}(450)$, $\mathrm{Ni@T_{iO } - x}(500)$, and $\mathrm{Ni}_{2} \mathrm{TiO}_{2-x}(600)$, respectively. (D) The enlarged view of the absorption edge selected from (C). Reprinted with permission from Reference [54]. Copyright 2017, American Chemical Society. 


\subsection{2. $\mathrm{H}_{2} \mathrm{O}$ Dissociation at $\mathrm{Ni} / \mathrm{TiO}_{2}$ Interface}

In the above work, the quantitative relation between interfacial site and reaction rate proved that the $\mathrm{Ni}^{\delta-}-\mathrm{O}_{\mathrm{v}}-\mathrm{Ti}^{3+}$ interfacial site is the active site. Furthermore, the reaction mechanism of $\mathrm{H}_{2} \mathrm{O}$ dissociation at $\mathrm{Ni}^{\delta-}-\mathrm{O}_{\mathrm{v}}-\mathrm{Ti}^{3+}$ interfacial site was proven by in situ EXAFS under $\mathrm{H}_{2} \mathrm{O}$ atmosphere (Figure 9) [55]. Upon exposure to $\mathrm{H}_{2} \mathrm{O}$ from 150 to $450{ }^{\circ} \mathrm{C}$, the white line of Ni K-edge shifts gradually to high photon energy (Figure 9A). This indicates the oxidation of metallic $\mathrm{Ni}$ at elevated temperature in $\mathrm{H}_{2} \mathrm{O}$ atmosphere. In addition, based on the FT $k^{2}$-weighted Ni K-edge EXAFS spectra, a peak at $\sim 3.08 \AA$ formed at $450^{\circ} \mathrm{C}$. It is due to the formation of the Ni-O-Ti bond. In situ CO-DRIFTS measurements was also used in this work to explore the electronic structure of $\mathrm{Ni}$ atom at the metal-support interfacial site. These results show the efficiency of in situ spectroscopy methodology in monitoring the structural and electronic dynamic evolution of metal-support interfacial sites. Recently, EMSI was also proven to exist in $\mathrm{Au} @ \mathrm{TiO}_{2-x}$ catalysts [56]. In situ EXAFS proves that the metal support interfacial site is the active site for WGSR. Both $\mathrm{Au}^{\delta-}$ species and $\mathrm{O}_{\mathrm{v}}$ directly participate in the water dissociation step (the rate-determining step for LT-WGSR).
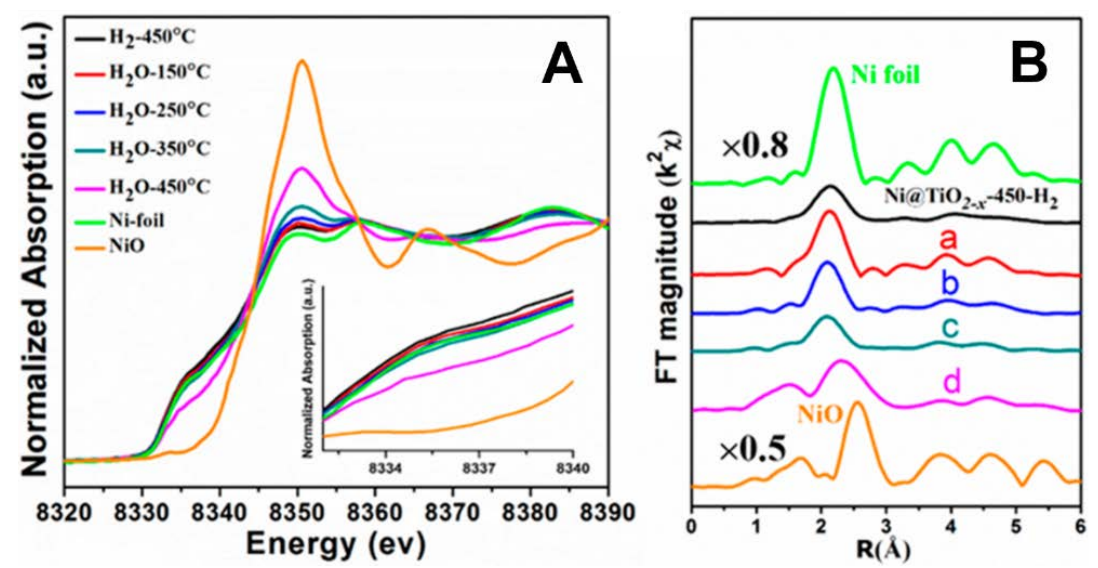

Figure 9. (A) Normalized Ni K-edge XANES spectra and (B) Fourier-transform Ni K-edge EXAFS spectra for $\mathrm{Ni}_{\mathrm{TiO}} \mathrm{Tix}_{2}(450)$ catalyst in $\mathrm{H}_{2} \mathrm{O}$ atmosphere at $150,250,350$, and $450{ }^{\circ} \mathrm{C}$, respectively. $\mathrm{Ni}$ foil and $\mathrm{NiO}$ reference sample: Room temperature. Reprinted with permission from Reference [55]. Copyright 2017, American Chemical Society.

\section{4. $\mathrm{CO}_{2}$ Hydrogenation}

$\mathrm{CO}_{2}$ hydrogenation is a promising reaction route to achieve carbon recycling. This not only contributes to the alleviation of environmental problems, but also has the potential to produce useful chemicals (e.g., $\mathrm{CH}_{3} \mathrm{OH}, \mathrm{CO}$, and $\mathrm{CH}_{4}$ ) [57]. Metal catalysts based on reducible metal oxides (e.g., $\mathrm{CeO}_{2}$, $\mathrm{TiO}_{2}$ ) are appropriate catalysts for $\mathrm{CO}_{2}$ conversion. Recently, the unique structural features and key reaction intermediates at the metal-support interface have been well studied with in situ/operando spectroscopy methodology.

\subsubsection{The $\mathrm{CO}_{2}$ Hydrogenation to $\mathrm{CH}_{3} \mathrm{OH}$ at $\mathrm{Cu} / \mathrm{CeO}_{2}$ Interface}

Rodriguez et al. found that the catalytic rate of the $\mathrm{CO}_{2}$ hydrogenation to methanol on $\mathrm{CeO}_{x} / \mathrm{Cu}(111)$ is significantly faster than those on $\mathrm{Cu}(111)$ and $\mathrm{Cu} / \mathrm{ZnO}(0001)$ [58]. The in situ infrared reflection absorption spectroscopy (IRRAS) and ambient-pressure (AP) XPS were employed to investigate the reaction intermediates at the $\mathrm{Cu}-\mathrm{Ce}$ interfaces for methanol synthesis from $\mathrm{CO}_{2}$. Under the reaction conditions (atmosphere: $\mathrm{CO}_{2}+\mathrm{H}_{2}, 500 \mathrm{~K}$ ), the characteristic peaks of carboxylate $\left(\mathrm{CO}_{2}{ }^{\delta-}, 1295 \mathrm{~cm}^{-1}\right)$ and formate species $\left(\mathrm{HCOO}^{-}, 1330,1370,1598,2858 \mathrm{~cm}^{-1}\right)$ were detected (Figure 10). A similar result was obtained in the AP-XPS spectrum under $\mathrm{CO}_{2} / \mathrm{H}_{2}$ mixture at $473 \mathrm{~K}$ on $\mathrm{CeO}_{x} / \mathrm{Cu}(111)$ surface. The main feature can be fitted with characteristic peaks of carboxylate $(288.4 \mathrm{eV})$ and formate $(289.2 \mathrm{eV})$, respectively. Considering the lower stability of carboxylate, it is a more active intermediate compared 
with formate. In this work, in situ spectroscopy studies played a key role in discriminating the new active reaction intermediates (carboxylate). This shows that the $\mathrm{CeO}_{x} / \mathrm{Cu}(111)$ surface is a new active site for $\mathrm{CO}_{2}$ activation. In their following catalytic system based on $\mathrm{Au} / \mathrm{CeO}_{x} / \mathrm{TiO}_{2}$ catalyst, the catalytic role of $\mathrm{CeO}_{\mathrm{x}}$ in activating $\mathrm{CO}_{2}$ and the active surface intermediates were further confirmed by in situ AP-XPS [59].

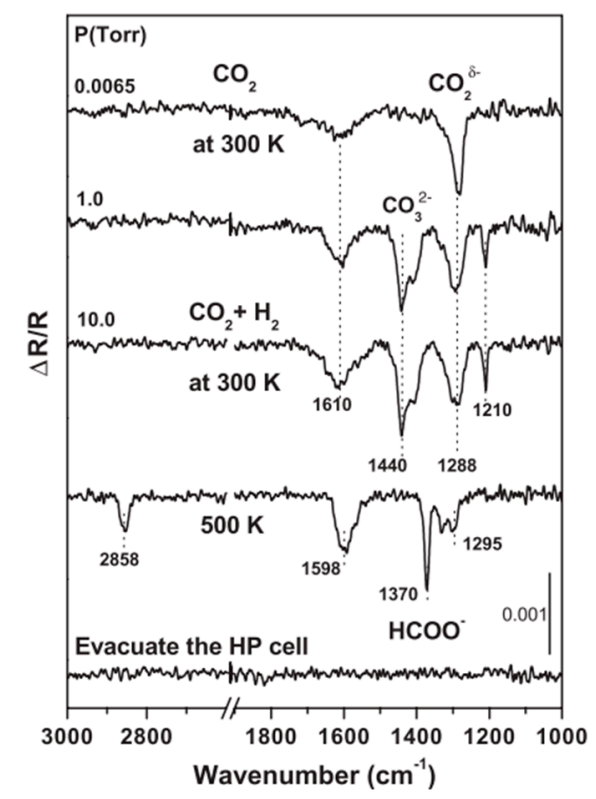

Figure 10. IRRAS spectra at ambient pressures. The spectra were obtained after the exposure of $\mathrm{CeO}_{x} / \mathrm{Cu}(111)$ to $\mathrm{CO}_{2}$ and $\mathrm{H}_{2}$ at the indicated pressures and temperatures. All the spectra except the one at the bottom were collected in the presence of $\mathrm{CO}_{2}$ or a $\mathrm{CO}_{2}+\mathrm{H}_{2}$ mixture at the indicated pressures. $\Delta R / R$, normalized reflectivity change. Reprinted with permission from Reference [58]. Copyright 2014, The American Association for the Advancement of Science.

\subsection{2. $\mathrm{CO}_{2}$ Hydrogenation to $\mathrm{CO} / \mathrm{CH}_{4}$ at $\mathrm{PtCo} / \mathrm{CeO}_{2}$ and $\mathrm{PtCo} / \mathrm{TiO}_{2}$ Interface}

The metal-support interaction can introduce large electronic perturbations to the interfacial atoms. This will directly affect the bonding properties of the catalyst with different reaction intermediates at the interface. Chen et al. found that PtCo bimetallic catalysts supported on different reducible oxides $\left(\mathrm{CeO}_{2}\right.$ and $\left.\mathrm{TiO}_{2}\right)$ have significantly different catalytic selectivities $\left(\mathrm{CO} / \mathrm{CH}_{4}\right)$ in $\mathrm{CO}_{2}$ hydrogenation reaction [60]. The in situ FTIR played a key role in illustrating this conclusion. On the one hand, formate intermediate forms on both $\mathrm{PtCo} / \mathrm{CeO}_{2}$ and $\mathrm{PtCo} / \mathrm{TiO}_{2}$ catalysts while ${ }^{*} \mathrm{CH}_{3} \mathrm{O}$ only forms on $\mathrm{PtCo} / \mathrm{CeO}$ (Figure 11A). On the other hand, using $\mathrm{HCOOH}$ and $\mathrm{CH}_{3} \mathrm{OH}$ as the probe molecules, formate and ${ }^{*} \mathrm{CH}_{3} \mathrm{O}$ are likely the precursors for the formation of $\mathrm{CO}$ and $\mathrm{CH}_{4}$, respectively (Figure 11B).

\subsection{3. $\mathrm{CO}_{2}$ Hydrogenation to $\mathrm{CH}_{3} \mathrm{OH} / \mathrm{CO}$ at the $\mathrm{Cu} / \mathrm{TiO}_{2}$ Interface}

Chen et al. further reported the tunable selectivity in $\mathrm{CO}_{2}$ hydrogenation over $\mathrm{Cu} / \mathrm{TiO}_{2}$ and $\mathrm{Cu} / \mathrm{ZrO}_{2}$ catalysts [61]. The in situ DRIFTS measurements played a part in detecting the absorbate species and discriminating their relative activities. Figure 12 shows that the formation rates of ${ }^{*} \mathrm{H}_{3} \mathrm{CO}$ and ${ }^{*} \mathrm{HCOO}$ are not related, indicating that the reaction does not occur via the formate route. However, the formation rate of $\mathrm{CO}$ is not shown by DRIFTS, which is thought to be the active reaction intermediate by the authors. 

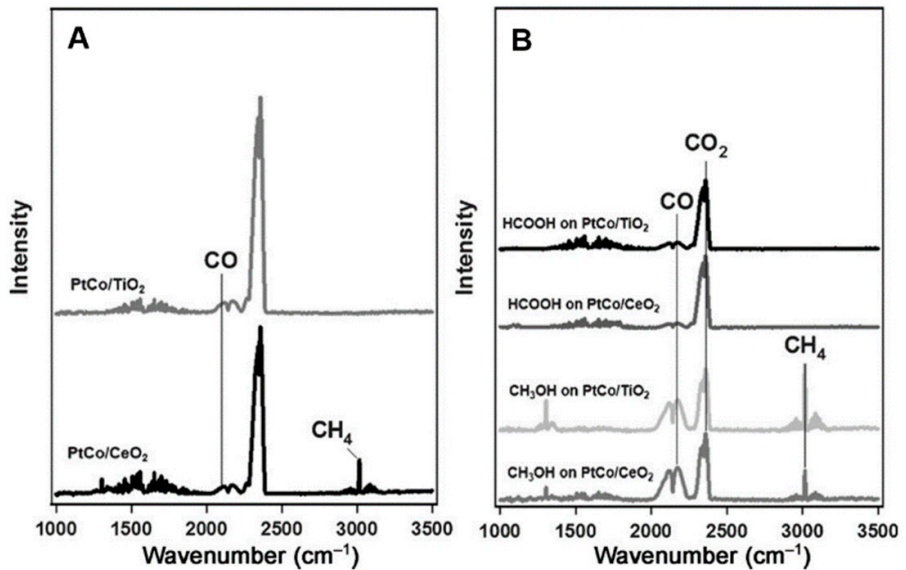

Figure 11. FTIR spectra recorded during (A) $\mathrm{CO}_{2}$ reduction in the presence of $\mathrm{H}_{2}$ and (B) the reactions of formic acid and methanol over $\mathrm{PtCo} / \mathrm{CeO}_{2}$ and $\mathrm{PtCo} / \mathrm{TiO}_{2}$ catalysts. Reprinted with permission from Reference [60]. Copyright 2016, John Wiley and Sons.

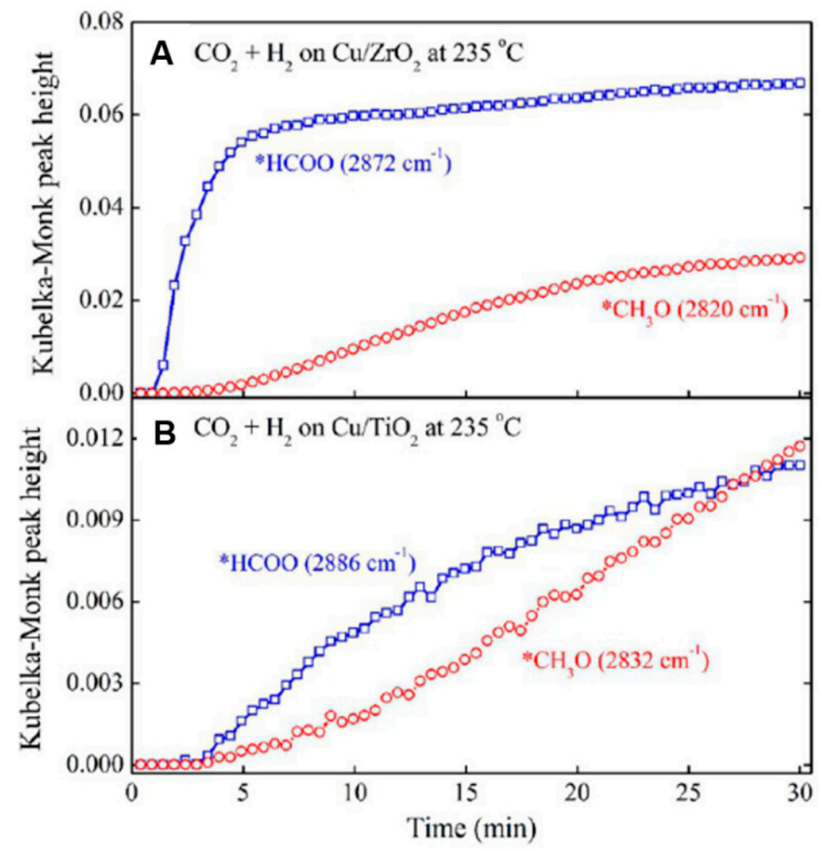

Figure 12. IR peak intensities of surface formate and methoxy species versus time during $\mathrm{CO}_{2}+\mathrm{H}_{2}$ reaction over $(\mathbf{A}) \mathrm{Cu} / \mathrm{ZrO}_{2}$ and $(\mathbf{B}) \mathrm{Cu} / \mathrm{TiO}_{2}$ catalysts. (Reaction conditions: $5 \mathrm{~mL} / \mathrm{min} \mathrm{CO}_{2}+15 \mathrm{~mL} / \mathrm{min}$ $\mathrm{H}_{2}, 0.1 \mathrm{MPa}, 235{ }^{\circ} \mathrm{C}$ ). Reprinted with permission from Reference [61]. Copyright 2016, American Chemical Society.

\subsection{4. $\mathrm{CO}_{2}$ Hydrogenation to $\mathrm{CH}_{4}$ at the $\mathrm{Ru} / \mathrm{CeO}_{2}$ Interface}

The oxygen vacancy is one of the unique structures for reducible oxide, which is thought to play an important role in a variety of reactions [62]. In 2015, our work found the quantitative relation between the reaction rate and surface oxygen vacancies. This indicated that the oxygen vacancy is the active site for $\mathrm{CO}_{2}$ methanation [63]. In order to understand the critical role of oxygen vacancies in the reaction, we used in situ XANES, IR, and Raman to study the structural evolvements of $\mathrm{Ce}^{3+}$, surface hydroxyl, and oxygen vacancy under the practical reaction conditions [64]. The results show that they need different activation temperature in the reaction (room temperature for $\mathrm{Ce}^{3+}$ and surface hydroxyl, $100{ }^{\circ} \mathrm{C}$ for oxygen vacancy). The reason is probably that they work in the different elementary steps of the catalytic cycle. The steady-state isotope transient kinetic analysis (SSITKA) type in situ DRIFT IR 
proved that $\mathrm{Ru}$ nanoparticles serve as the active sites for the $\mathrm{CO}$ route starting from $250{ }^{\circ} \mathrm{C}$ (Figure 13). However, the transformation of formate to methanol and the successful production of $\mathrm{CH}_{4}$ occur at about $100-150{ }^{\circ} \mathrm{C}$. This is a similar temperature as that required for the activation of oxygen vacancy (about 100 to $200{ }^{\circ} \mathrm{C}$ ), proving that the oxygen vacancy plays a key role in the dissociation of formate to methanol in the formate route.
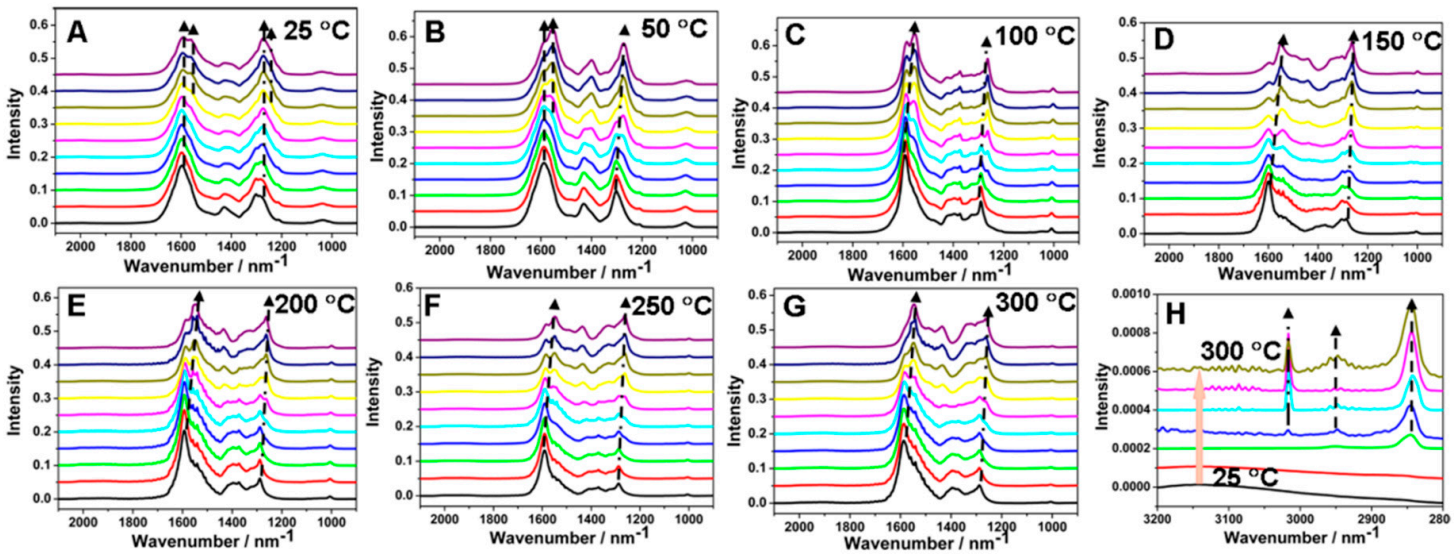

Figure 13. Operando DRIFT spectra recorded over $\mathrm{Ru} / \mathrm{CeO}_{2}$ catalyst by introducing $13 \mathrm{CO}_{2}$ and $\mathrm{H}_{2}$ as reaction gas after $90 \mathrm{~min}$ of equilibrium reaction in $12 \mathrm{CO}_{2}$ and $\mathrm{H}_{2}$. From bottom to top in each panel: $0,0.5,1,1.5,2,3,5,7,10$, and $15 \mathrm{~min}$. From A to G: $25,50,100,150,200,250$, and $300{ }^{\circ} \mathrm{C}$. (H) The DRIFT spectra of $\mathrm{CH}_{4}$ recorded over $\mathrm{Ru} / \mathrm{CeO}_{2}$ catalyst after 90 min of equilibrium reaction in $12 \mathrm{CO}_{2}$ and $\mathrm{H}_{2}$. From bottom to top: $25,50,100,150,200,250$, and $300{ }^{\circ} \mathrm{C}$. Reprinted with permission from Reference [64]. Copyright 2016, American Chemical Society.

\subsection{Unsaturated Aldehyde Hydrogenation}

The ambient pressure sum frequency generation (SFG) vibrational spectroscopy is a surface sensitive method to observe surface reaction intermediates, which is commonly used on single crystals and shape-controlled nanoparticles [65]. In 2012, Somorjai et al. used SFG to probe the oxide-metal interface in the hydrogenation of furfuraldehyde for the first time [66]. The charged reaction intermediate is highly active and selective to a specific product. In 2014, a similar result was attained in the hydrogenation of crotonaldehyde on $\mathrm{Pt} / \mathrm{TiO}_{2}$ [67].

\section{Conclusions}

To add to the research on heterogeneous catalysis with reducible metal oxides as supports, this review article summarizes the recent progress using in situ/operando spectroscopy methodology. On the one hand, four kinds of intimate metal-support interactions are summarized, including the strong metal-support interaction (SMSI), adsorbate-mediated SMSI (A-SMSI), wet-chemistry SMSI (wcSMSI), and electronic metal-support interactions (EMSI). On the other hand, the structure-activity relationship at the metal-support interfacial sites in three important catalytic reactions is summarized, including $\mathrm{CO}$ oxidation, WGSR, and $\mathrm{CO}_{2}$ hydrogenation. Although much progress has been made, great challenges still remain in this area, some of which are listed as follows: (1) It is hard to control the extent of partial decoration of metal nanoparticles by oxide overlayers for real catalysts. The preparation of catalysts via the structure topotactic transformation of layered double hydroxide (LDHs) precursor is a good method. The reduction treatment at different temperatures can finely tune the extent of partial decoration. (2) It is a challenge to clearly make a distinction between active reaction intermediates and precursors for the adsorbed species. The steady-state isotope transient kinetic analysis (SSITKA) type in situ infrared spectroscopy is an effective method by correlating buildup/decay of surface species. However, it should be noted that the peak shift of adsorbed species may result from thermal desorption rather than catalytic conversion. (3) It is hard to confirm the real rate-determining step in 
the reaction mechanism. This problem is likely due to the excessive reaction temperature, which leads to an undetectable concentration of reaction intermediate on the surface of the catalyst. The detection effect can be improved by lowing the reaction temperature. With the rapid advance of in situ/operando spectroscopy methodology, the structure-activity relationship for metal catalysts supported on reducible oxides will gradually have more light spread upon it, which will be beneficial for the rational design of heterogeneous catalysts.

Funding: This research received no external funding.

Conflicts of Interest: The authors declare no conflict of interest.

\section{References}

1. Ryczkowski, J. IR spectroscopy in catalysis. Catal. Today 2001, 68, 263-381. [CrossRef]

2. Venezia, A.M. X-ray photoelectron spectroscopy (XPS) for catalysts characterization. Catal. Today 2003, 77, 359-370. [CrossRef]

3. Stacchiola, D.J. Tuning the properties of copper-based catalysts based on molecular in situ studies of model systems. Acc. Chem. Res. 2015, 48, 2151-2158. [CrossRef] [PubMed]

4. Bañares, M.A. Operando methodology: Combination of in situ spectroscopy and simultaneous activity measurements under catalytic reaction conditions. Catal. Today 2005, 100, 71-77. [CrossRef]

5. Chakrabarti, A.; Ford, M.E.; Gregory, D.; Hu, R.; Keturakis, C.J.; Lwin, S.; Tang, Y.; Yang, Z.; Zhu, M.; Bañares, M.A.; et al. A decade plus of operando spectroscopy studies. Catal. Today 2017, 283, 27-53. [CrossRef]

6. Zanella, R.; Giorgio, S.; Shin, C.; Henry, C.R.; Louis, C. Characterization and reactivity in CO oxidation of gold nanoparticles supported on $\mathrm{TiO}_{2}$ prepared by deposition-precipitation with $\mathrm{NaOH}$ and urea. J. Catal. 2004, 222, 357-367. [CrossRef]

7. Zhu, H.; Qin, Z.; Shan, W.; Shen, W.; Wang, J. Pd/ $\mathrm{CeO}_{2}-\mathrm{TiO}_{2}$ catalyst for $\mathrm{CO}$ oxidation at low temperature: A TPR study with $\mathrm{H}_{2}$ and $\mathrm{CO}$ as reducing agents. J. Catal. 2004, 225, 267-277. [CrossRef]

8. Carrettin, S.; Concepción, P.; Corma, A.; López Nieto, J.M.; Puntes, V.F. Nanocrystalline $\mathrm{CeO}_{2}$ increases the activity of $\mathrm{Au}$ for $\mathrm{CO}$ oxidation by two orders of magnitude. Angew. Chem. Int. Ed. 2004, 43, 2538-2540. [CrossRef]

9. Wu, Z.; Li, M.; Overbury, S.H. On the structure dependence of $\mathrm{CO}$ oxidation over $\mathrm{CeO}_{2}$ nanocrystals with well-defined surface planes. J. Catal. 2012, 285, 61-73. [CrossRef]

10. Luengnaruemitchai, A.; Osuwan, S.; Gulari, E. Comparative studies of low-temperature water-gas shift reaction over $\mathrm{Pt} / \mathrm{CeO}_{2}, \mathrm{Au} / \mathrm{CeO}_{2}$, and $\mathrm{Au} / \mathrm{Fe}_{2} \mathrm{O}_{3}$ catalysts. Catal. Commun. 2003, 4, 215-221. [CrossRef]

11. Fu, Q.; Weber, A.; Flytzani-Stephanopoulos, $\mathrm{M}$. Nanostructured $\mathrm{Au}-\mathrm{CeO}_{2}$ catalysts for low-temperature water-gas shift. Catal. Lett. 2001, 77, 87-95. [CrossRef]

12. Panagiotopoulou, P.; Kondarides, D.I. Effect of morphological characteristics of $\mathrm{TiO}_{2}$-supported noble metal catalysts on their activity for the water-gas shift reaction. J. Catal. 2004, 225, 327-336. [CrossRef]

13. Rodriguez, J.A.; Liu, P.; Hrbek, J.; Evans, J.; Pérez, M. Water gas shift reaction on Cu and Au nanoparticles supported on $\mathrm{CeO}_{2}(111)$ and $\mathrm{ZnO}(0001)$ : Intrinsic activity and importance of support interactions. Angew. Chem. Int. Ed. 2007, 46, 1329-1332. [CrossRef] [PubMed]

14. Park, J.N.; McFarland, E.W. A highly dispersed $\mathrm{Pd}-\mathrm{Mg} / \mathrm{SiO}_{2}$ catalyst active for methanation of $\mathrm{CO}_{2}$. J. Catal. 2009, 266, 92-97. [CrossRef]

15. Corma, A.; Garcia, H. Photocatalytic reduction of $\mathrm{CO}_{2}$ for fuel production: Possibilities and challenges. J. Catal. 2013, 308, 168-175. [CrossRef]

16. Hakim, S.H.; Sener, C.; Alba-Rubio, A.C.; Gostanian, T.M.; O’Neill, B.J.; Ribeiro, F.H.; Miller, J.T.; Dumesic, J.A. Synthesis of supported bimetallic nanoparticles with controlled size and composition distributions for active site elucidation. J. Catal. 2015, 328, 75-90. [CrossRef]

17. Centi, G.; Iaquaniello, G.; Perathoner, S. Can we afford to waste carbon dioxide? Carbon dioxide as a valuable source of carbon for the production of light olefins. ChemSusChem 2011, 4, 1265-1273. [CrossRef]

18. Ma, J.; Sun, N.N.; Zhang, X.L.; Zhao, N.; Mao, F.K.; Wei, W.; Sun, Y.H. A short review of catalysis for CO2 conversion. Catal. Today 2009, 148, 221-231. [CrossRef]

19. Haller, G.L.; Resasco, D.E. Metal support interaction-group-VIII metals and reducible oxides. Adv. Catal. 1989, 36, 173-235. [CrossRef] 
20. Ioannides, T.; Verykios, X.E. Charge transfer in metal catalysts supported on doped $\mathrm{TiO}_{2}$ : A theoretical approach based on metal-semiconductor contact theory. J. Catal. 1996, 161, 560-569. [CrossRef]

21. Farmer, J.A.; Campbell, C.T. Ceria maintains smaller metal catalyst particles by strong metal-support bonding. Science 2010, 329, 933-936. [CrossRef]

22. Saavedra, J.; Doan, H.A.; Pursell, C.J.; Grabow, L.C.; Chandler, B.D. The critical role of water at the gold-titania interface in catalytic CO oxidation. Science 2014, 345, 1599-1602. [CrossRef]

23. Tauster, S.J.; Fung, S.C.; Garten, R.L. Strong metal-support interactions. Group VIII noble metals supported on Titania. J. Am. Chem. Soc. 1978, 100, 170-175. [CrossRef]

24. Datye, A.K.; Kalakkad, D.S.; Yao, M.H.; Smith, D.J. Comparison of metal-support interactions in Pt/TiO 2 and $\mathrm{Pt} / \mathrm{CeO}_{2}$. J. Catal. 1995, 155, 148-153. [CrossRef]

25. Freund, H.J.; Pacchioni, G. Oxide ultra-thin films on metals: New materials for the design of supported metal catalysts. Chem. Soc. Rev. 2008, 37, 2224-2242. [CrossRef]

26. Suzuki, T.; Souda, R. The encapsulation of $\mathrm{Pd}$ by the supporting $\mathrm{TiO}_{2}(110)$ surface induced by strong metal-support interactions. Surf. Sci. 2000, 448, 33-39. [CrossRef]

27. Bowker, M.; Stone, P.; Morrall, P.; Smith, R.; Bennett, R.; Perkins, N.; Kvon, R.; Pang, C.; Fourre, E.; Hall, M. Model catalyst studies of the strong metal-support interaction: Surface structure identified by STM on Pd nanoparticles on TiO2(110). J. Catal. 2005, 234, 172-181. [CrossRef]

28. Bennett, R.A.; Pang, C.L.; Perkins, N.; Smith, R.D.; Morrall, P.; Kvon, R.I.; Bowker, M. Surface structures in the SMSI state; Pd on $(1 \times 2)$ reconstructed $\mathrm{TiO}_{2}(110)$. J. Phys. Chem. B 2002, 106, 4688-4696. [CrossRef]

29. Fu, Q.; Wagner, T.; Olliges, S.; Carstanjen, H.-Z. Metal-oxide interfacial reactions: Encapsulation of Pd on $\mathrm{TiO}_{2}$ (110). J. Phys. Chem. B 2005, 109, 944-951. [CrossRef]

30. Somorjai, G.A.; Park, J.Y. Frontiers of surface science. Phys. Today 2007, 60, 48-53. [CrossRef]

31. Somorjai, G.A.; York, R.L.; Butcher, D.; Park, J.Y. The evolution of model catalytic systems; studies of structure, bonding and dynamics from single crystal metal surfaces to nanoparticles, and from low pressure $(<10-3$ Torr) to high pressure ( $>10$ - 3 Torr) to liquid interfaces. Phys. Chem. Chem. Phys. 2007, 9, 3500-3513. [CrossRef]

32. Li, H.; Weng, X.; Tang, Z.; Zhang, H.; Ding, D.; Chen, M.; Wan, H. Evidence of the encapsulation model for strong metal-support interaction under oxidized conditions: A case study on $\mathrm{TiO} / \mathrm{Pt}(111)$ for $\mathrm{CO}$ oxidation by in situ wide spectral range infrared reflection adsorption spectroscopy. ACS Catal. 2018, 8, 10156-10163. [CrossRef]

33. Matsubu, J.C.; Zhang, S.; DeRita, L.; Marinkovic, N.S.; Chen, J.G.; Graham, G.W.; Pan, X.; Christopher, P. Adsorbate-mediated strong metal-support interactions in oxide-supported Rh catalysts. Nat. Chem. 2017, 9, 120-127. [CrossRef] [PubMed]

34. Henderson, M.A. Complexity in the decomposition of formic acid on the TiO2(110) surface. J. Phys. Chem. B 1997, 101, 221-229. [CrossRef]

35. Diebold, U. The surface science of titanium dioxide. Surf. Sci. Rep. 2003, 48, 53-229. [CrossRef]

36. Morikawa, Y.; Takahashi, I.; Aizawa, M.; Namai, Y.; Sasaki, T.; Iwasawa, Y. First-principles theoretical study and scanning tunneling microscopic observation of dehydration process of formic acid on a $\mathrm{TiO} 2(110)$ surface. J. Phys. Chem. B 2004, 108, 14446-14451. [CrossRef]

37. Zhang, J.; Wang, H.; Wang, L.; Ali, S.; Wang, C.; Wang, L.; Meng, X.; Li, B.; Su, D.S.; Xiao, F. Wet-chemistry strong metal-support interactions in titania supported Au catalysts. J. Am. Chem. Soc. 2019, 141, 2975-2983. [CrossRef]

38. Bruix, A.; Rodriguez, J.A.; Ramrez, P.J.; Senanayake, S.D.; Evans, J.; Park, J.B.; Stacchiola, D.; Liu, P.; Hrbek, J.; Illas, F. A new type of strong metal-support interaction and the production of $\mathrm{H}_{2}$ through the transformation of water on $\mathrm{Pt} / \mathrm{CeO}_{2}(111)$ and $\mathrm{Pt} / \mathrm{CeO}_{x} / \mathrm{TiO}_{2}$ (110) Catalysts. J. Am. Chem. Soc. 2012, 134, 8968-8974. [CrossRef]

39. Campbell, C.T. Catalyst-support interactions electronic perturbations. Nat. Chem. 2012, 4, 597-598. [CrossRef]

40. Cargnello, M.; Doan-Nguyen, V.T.; Gordon, T.R.; Diaz, R.E.; Stach, E.A.; Gorte, R.J.; Fornasiero, P.; Murray, C.B. Control of metal nanocrystal size reveals metal-support interface role for ceria catalysts. Science 2013, 341 , 771-773. [CrossRef] [PubMed]

41. An, K.; Alayoglu, S.; Musselwhite, N.; Plamthottam, S.; Melaet, G.; Lindeman, A.E.; Somorjai, G.A. Enhanced $\mathrm{CO}$ oxidation rates at the interface of mesoporous oxides and Pt nanoparticles. J. Am. Chem. Soc. 2013, 135, 16689-16696. [CrossRef] [PubMed]

42. Green, I.X.; Tang, W.; Neurock, M.; Yates, J.T., Jr. Spectroscopic observation of dual catalytic sites during oxidation of $\mathrm{CO}$ on a $\mathrm{Au} / \mathrm{TiO}_{2}$ Catalyst. Science 2011, 333, 736-739. [CrossRef] [PubMed] 
43. Wang, Y.; Widmann, D.; Behm, R.J. Influence of $\mathrm{TiO}_{2}$ bulk defects on $\mathrm{CO}$ adsorption and $\mathrm{CO}$ oxidation on $\mathrm{Au} / \mathrm{TiO}_{2}$ : Electronic metal-support interactions (EMSIs) in supported Au catalysts. ACS Catal. 2017, 7, 2339-2345. [CrossRef]

44. Wang, Y.; Widmann, D.; Heenemann, M.; Diemant, T.; Biskupek, J.; Schlögl, R.; Behm, R.J. The role of electronic metal-support interactions and its temperature dependence: $\mathrm{CO}$ adsorption and $\mathrm{CO}$ oxidation on $\mathrm{Au} / \mathrm{TiO}_{2}$ catalysts in the presence of $\mathrm{TiO}_{2}$ bulk defects. J. Catal. 2017, 354, 46-60. [CrossRef]

45. Kopelent, R.; van Bokhoven, J.A.; Szlachetko, J.; Edebeli, J.; Paun, C.; Nachtegaal, M.; Safonova, O.V. Catalytically active and spectator $\mathrm{Ce}^{3+}$ in ceria-supported metal catalysts. Angew. Chem. Int. Ed. 2015, 54, 8728-8731. [CrossRef] [PubMed]

46. Kim, J.; Park, W.H.; Doh, W.H.; Lee, S.W.; Noh, M.C.; Gallet, J.; Bournel, F.; Kondoh, H.; Mase, K.; Jung, Y.; et al. Adsorbate-driven reactive interfacial $\mathrm{Pt}-\mathrm{NiO}_{1-\mathrm{x}}$ nanostructure formation on the $\mathrm{Pt}_{3} \mathrm{Ni}(111)$ alloy surface. Sci. Adv. 2018, 4, eaat3151. [CrossRef] [PubMed]

47. Lee, H.; Lim, J.; Lee, C.; Back, S.; An, K.; Shin, J.W.; Ryoo, R.; Jung, Y.; Park, J.Y. Boosting hot electron flux and catalytic activity at metal-oxide interfaces of PtCo bimetallic nanoparticles. Nat. Commun. 2018, 9, 2235. [CrossRef]

48. Osman, A.I.; Abu-Dahrieh, J.K.; Laffir, F.; Curtin, T.; Thompson, J.M.; Rooney, D.W. A bimetallic catalyst on a dual component support for low temperature total methane oxidation. Appl. Catal. B 2016, 187, 408-418. [CrossRef]

49. Osman, A.I.; Meudal, J.; Laffir, F.; Thompson, J.; Rooney, D. Enhanced catalytic activity of $\mathrm{Ni}$ on $\eta-\mathrm{Al}_{2} \mathrm{O}_{3}$ and ZSM-5 on addition of ceria zirconia for the partial oxidation of methane. Appl. Catal. B 2017, 212, 68-79. [CrossRef]

50. Fouladvand, S.; Skoglundh, M.; Carlsson, P. A transient in situ infrared spectroscopy study on methane oxidation over supported Pt catalysts. Catal. Sci. Technol. 2014, 4, 3463-3473. [CrossRef]

51. Osman, A.I.; Abu-Dahrieh, J.K.; McLaren, M.; Laffir, F.; Rooney, D.W. Characterisation of robust combustion catalyst from aluminium foil waste. ChemistrySelect 2018, 3, 1545-1550. [CrossRef]

52. Osman, A.I.; Abu-Dahrieh, J.K.; Cherkasov, N.; Fernandez-Garcia, J.; Walker, D.; Walton, R.I.; Rooney, D.W.; Rebrov, E. A highly active and synergistic $\mathrm{Pt} / \mathrm{Mo}_{2} \mathrm{C} / \mathrm{Al}_{2} \mathrm{O}_{3}$ catalyst for water-gas shift reaction. Mol. Catal. 2018, 455, 38-47. [CrossRef]

53. Mudiyanselage, K.; Senanayake, S.D.; Feria, L.; Kundu, S.; Baber, A.E.; Graciani, J.; Vidal, A.B.; Agnoli, S.; Evans, J.; Chang, R.; et al. Importance of the metal-oxide interface in catalysis: In situ studies of the water-gas shift reaction by ambient-pressure X-ray photoelectron spectroscopy. Angew. Chem. Int. Ed. 2013, 52, 5101-5105. [CrossRef] [PubMed]

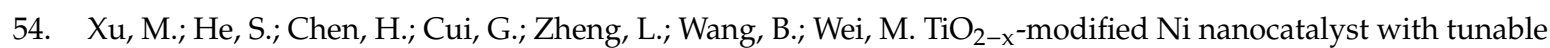
metal-support interaction for water-gas shift reaction. ACS Catal. 2017, 7, 7600-7609. [CrossRef]

55. Xu, M.; Yao, S.; Rao, D.; Niu, Y.; Liu, N.; Peng, M.; Zhai, P.; Man, Y.; Zheng, L.; Wang, B.; et al. Insights into interfacial synergistic catalysis over $\mathrm{Ni}_{\mathrm{TiO}} \mathrm{Tix}_{2}$ catalyst toward water-gas shift reaction. J. Am. Chem. Soc. 2018, 140, 11241-11252. [CrossRef] [PubMed]

56. Liu, N.; Xu, M.; Yang, Y.; Zhang, S.; Zhang, J.; Wang, W.; Zheng, L.; Hong, S.; Wei, M. Au ${ }^{\delta-}-\mathrm{O}_{\mathrm{v}}-\mathrm{Ti}^{3+}$ interfacial site: Catalytic active center toward low-temperature water gas shift reaction. ACS Catal. 2019, 9, 2707-2717. [CrossRef]

57. Wang, F.; Wei, M.; Evans, D.G.; Duan, X. $\mathrm{CeO}_{2}$-based heterogeneous catalysts toward catalytic conversion of $\mathrm{CO}_{2}$. J. Mater. Chem. A 2016, 4, 5773-5783. [CrossRef]

58. Graciani, J.; Mudiyanselage, K.; Xu, F.; Baber, A.E.; Evans, J.; Senanayake, S.D.; Stacchiola, D.J.; Liu, P.; Hrbek, J.; Sanz, J.F.; et al. Highly active copper-ceria and copper-ceria-titania catalysts for methanol synthesis from $\mathrm{CO}_{2}$. Science 2014, 345, 546-550. [CrossRef] [PubMed]

59. Yang, X.; Kattel, S.; Senanayake, S.D.; Boscoboinik, J.A.; Nie, X.; Graciani, J.; Rodriguez, J.A.; Liu, P.; Stacchiola, D.J.; Chen, J.G. Low pressure $\mathrm{CO}_{2}$ hydrogenation to methanol over gold nanoparticles activated on $\mathrm{CeO}_{\mathrm{x}} / \mathrm{TiO}_{2}$ interface. J. Am. Chem. Soc. 2015, 137, 10104-10107. [CrossRef]

60. Kattel, S.; Yu, W.; Yang, X.; Yan, B.; Huang, Y.; Wan, W.; Liu, P.; Chen, J.G. $\mathrm{CO}_{2}$ hydrogenation over oxide-supported PtCo catalysts: The role of the oxide support in determining the product selectivity. Angew. Chem. Int. Ed. 2016, 55, 7968-7973. [CrossRef] 
61. Kattel, S.; Yan, B.; Yang, Y.; Chen, J.G.; Liu, P. Optimizing binding energies of key intermediates for $\mathrm{CO}_{2}$ hydrogenation to methanol over oxide-supported copper. J. Am. Chem. Soc. 2016, 138, 12440-12450. [CrossRef] [PubMed]

62. Esch, F.; Fabris, S.; Zhou, L.; Montini, T.; Africh, C.; Fornasiero, P.; Comelli, G.; Roser, R. Electron localization determines defect formation on ceria substrates. Science 2005, 309, 752-755. [CrossRef] [PubMed]

63. Wang, F.; Li, C.; Zhang, X.; Wei, M.; Evans, D.G.; Duan, X. Catalytic behavior of supported Ru nanoparticles on the $\{100\},\{110\}$, and $\{111\}$ facet of $\mathrm{CeO}_{2}$. J. Catal. 2015, 329, 177-186. [CrossRef]

64. Wang, F.; He, S.; Chen, H.; Wang, B.; Zheng, L.; Wei, M.; Evans, D.G.; Duan, X. Active site dependent reaction mechanism over $\mathrm{Ru} / \mathrm{CeO}_{2}$ catalyst toward $\mathrm{CO}_{2}$ methanation. J. Am. Chem. Soc. 2016, 138, 6298-6305. [CrossRef] [PubMed]

65. Shen, Y.R. Surface properties probed by second-harmonic and sum-frequency generation. Nature 1989, 337, 519-525. [CrossRef]

66. Baker, L.R.; Kennedy, G.; Spronsen, M.V.; Hervier, A.; Cai, X.; Chen, S.; Wang, L.; Somorjai, G.A. Furfuraldehyde hydrogenation on titanium oxide-supported platinum nanoparticles studied by sum frequency generation vibrational spectroscopy: Acid-base catalysis explains the molecular origin of strong metal-support interactions. J. Am. Chem. Soc. 2012, 134, 14208-14216. [CrossRef] [PubMed]

67. Kennedy, G.; Baker, L.R.; Somorjai, G.A. Selective amplification of C=O bond hydrogenation on $\mathrm{Pt} / \mathrm{TiO}{ }_{2}$ : Catalytic reaction and sum-frequency generation vibrational spectroscopy studies of crotonaldehyde hydrogenation. Angew. Chem. Int. Ed. 2014, 53, 3405-3408. [CrossRef] [PubMed]

(C) 2019 by the authors. Licensee MDPI, Basel, Switzerland. This article is an open access article distributed under the terms and conditions of the Creative Commons Attribution (CC BY) license (http://creativecommons.org/licenses/by/4.0/). 